\section{Hospital Stay in Nosocomial Infections}

\author{
Herry Gama
}

(Department of Child Health, Medical School, Padjadjaran University / Hasan Sadikin Hospital, Bandung )

Abstract. A 9-month prospective study on nosocomial infections was held from August 1988 till April 1989 at the Department of Child Health, Medical School, Padjadjaran University, August 1988 ill April 1989 Bandung. The purpose of the study was to compare the duration University, Hasan Sadikin Hospital without nosocomial infections. The Department of Child Health has 4 main wards. $A 2$ in patients with and families), A3 (for middle and high socioeconomic families), R-17 (for main wards, A2 (for low socioeconomic hospitalized pediatric patients observed consisting of 293 children ( $(57.5 \%)$ in R-17, and 63 children (1.4\%) in NICU. There were 128 ep 22 in A3, 220 in R-17, and 41 episodes in NICU, showing rates of episodes of nosocomial infections in A2, $65.1 \%$ in NICU. The means hospital stay of patients with rates of $9.9 \%$ in $A 2,4.5 \%$ in A3, $8.8 \%$ in R-17 and in $A 2$ and NICU, while in $A 3$ and $R-1717.61$ and with nosocomial infections were 26.77 and 22.44 days nosocomial infections were 13.11 and 9.24 and Length of stay specific nosocomial inf 3.10 days in $A 3$ and R-17. patients staying up to 6 days, $16.7 \%$ of pation rate rose with the duration of hospitalization, with $3.2 \%$ of and $48.8 \%$ of patients staying 35 of patients staying $7-13$ days, $19.7 \%$ of patients staying 14 to $20.2 \%$ of higher the number of noy infection was 2.4 lines infection was 2.4 times higher than that without nosocomial infection.

\section{Introduction}

Nosocomial infections are important in terms of patient morbidity, mortality, and additional hospital costs. ${ }^{1}$ Case-contro studies, in which patients with noso comial infections are matched with uninfected patients, have clearly demonstrated that nosocomial infections prolonged hospitalization significantly. ${ }^{2.3}$ Over half of the incrementa

Received: February 13, 1993 tions are thought to be accounted for by the per diem charges of the additional stay. ${ }^{4}$ In the United States the average prolongation of hospital stay resulting from nosocomial infection is approximately four days. However, the prolongation varies for the four major sites of infection. ${ }^{5}$ Girard et al. found and incoming from low socioeconomic families, crease in length of hospital stay of $23 \%$ for neonates with acquired nosocomial infections at Centre Hospitalier Lyon-Sud, France. ${ }^{6}$ The objective of this study was

\section{Materials and Methods}

The study was held at the Department of Child Health, Medical School, Padjadjaran University, Hasan Sadikin Hospital, Bandung. It was a prospective study of 9month duration, from August 1, 1988 till April 30, 1989, investigating the incidence of nosocomial infections.

The Department of Child Health has four main wards, A2, A3, R-17 and NICU. The A2 ward is particularly for patients whereas the A3 ward for pediatric patients of high and middle socioeconomic families. Ward R-17 is the neonatal ward, while NICU is for critically ill neonates. Patient's records and case finding by trained nurses were used as the basis for detecting nosocomial infections. During the study period a careful monitoring of records of all patients movements was held. The following information were recorded: name, medical record number, data of birth, date of admission, date of discharge, and diagnosis. Infection data

to compare the duration of hospitalization in pediatric patients with and without nosocomial infections.

were recorded in a special nosocomial infection form by those trained nurses. During that time, none of the selected and already trained nurses were transferred either from one ward to another in the department or to any other department in the hospital.

Every trained nurse reported a new suspected nosocomial infection case in her ward to the investigator, who then immediately examined the patient and checked the patient's record. If a nosocomial infection was suspected the nurse completed all the forms needed. These forms were then rechecked and corrected if-errors were-present by the investigator together with the nurse. After all the forms were completed, data cleaning and verification of these completed questionnaires were done by the investigator to ensure that no data were missed or had escaped the attention before computerization. Statistical analysis was done by using frequency distribution and chi-square.

\section{Results}

During the 9-month study a total number of 4328 hospitalized pediatric patients were observed, consisting of 293 children (29.9\%) in ward A2, 485 (11.2\%) in ward A3, 2487 (57.5\%) in ward R-17, and 63 children (1.4\%) in NICU. It revealed that among them a total number of 342 patients had one and or more nosocomial infections, yielding 411 episodes of nosocomial infections. 
Table 1. Nosocomial infections rate according to month and ward

\begin{tabular}{|c|c|c|c|c|c|c|c|c|c|c|c|c|c|c|c|}
\hline \multirow[b]{2}{*}{ Period } & \multicolumn{3}{|c|}{ A2 } & \multicolumn{3}{|c|}{ A3 } & \multicolumn{3}{|c|}{ R17 } & \multicolumn{3}{|c|}{ NICU } & \multicolumn{3}{|c|}{ Overall } \\
\hline & $\begin{array}{l}\text { No. } \\
\text { of } \\
\text { infs. }\end{array}$ & $\begin{array}{l}\text { No. } \\
\text { of } \\
\text { ptns }\end{array}$ & $\begin{array}{l}\mathrm{NI} \\
\text { rate } \\
\% \\
\end{array}$ & $\begin{array}{l}\text { No. } \\
\text { of } \\
\text { infs. }\end{array}$ & $\begin{array}{l}\text { No. } \\
\text { of } \\
\text { pins }\end{array}$ & $\begin{array}{l}\text { NI } \\
\text { rate } \\
\% \\
\end{array}$ & $\begin{array}{l}\text { No. } \\
\text { of } \\
\text { infs. }\end{array}$ & $\begin{array}{l}\text { No. } \\
\text { of } \\
\text { ptns }\end{array}$ & $\begin{array}{l}\mathrm{NI} \\
\text { rate } \\
\% \\
\end{array}$ & $\begin{array}{l}\text { No. } \\
\text { of } \\
\text { infs. }\end{array}$ & $\begin{array}{l}\text { No. } \\
\text { of } \\
\text { ptns }\end{array}$ & $\begin{array}{l}\mathrm{NI} \\
\text { rate } \\
\%\end{array}$ & $\begin{array}{l}\text { No. } \\
\text { of } \\
\text { infs. }\end{array}$ & $\begin{array}{l}\text { No. } \\
\text { of } \\
\text { ptns }\end{array}$ & $\begin{array}{l}\text { NI } \\
\text { rate } \\
\%\end{array}$ \\
\hline \multicolumn{16}{|l|}{$\begin{array}{l}1988 \\
\text { Auqust }\end{array}$} \\
\hline August & 18 & 229 & 7.9 & 2 & 88 & 2.3 & 43 & 318 & 13.5 & 6 & & 100.0 & 59 & $641^{-}$ & 10.8 \\
\hline Sept & 3 & 146 & 8.9 & 1 & 57 & 1.8 & 45 & 285 & 15.8 & 7 & & 1174.0 & 66 & 492 & 13.4 \\
\hline October & 15 & 142 & 10.6 & 2 & 45 & 4.4 & 57. & 300 & 19.0 & 3 & & 42.9 & 77 & 494 & 15.6 \\
\hline November & 414 & 150 & 9.3 & 5 & 43 & 11.6 & 24 & 260 & 9.2 & 9 & & 112.5 & 52 & 461 & 11.3 \\
\hline ecember & 18 & 159 & 11.3 & 0 & 69 & 0 & 14 & 258 & 5.4 & 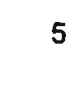 & 6 & 83.3 & 37 & 492 & 7.5 \\
\hline January & 20 & 131 & 15.3 & 3 & 49 & 6.1 & 7 & 261 & 2.7 & 5 & 8 & 62.5 & 35 & 449 & 7.8 \\
\hline =ebruary & 14 & 108 & 13.0 & 3 & 38 & 7.9 & 12 & 247 & 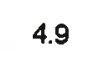 & 2 & 3 & 66.7 & 31 & 369 & 7.8 \\
\hline March & 13 & 121 & 10.7 & 2 & 52 & 0.0 & 5 & 270 & 1.9 & 2 & 6 & 33.3 & 22 & 449 & 4.9 \\
\hline April & 3 & 107 & 2.8 & 4 & 44 & 9.1 & 13 & 288 & 4.5 & 2 & 15 & 13.3 & 22 & 454 & 4.8 \\
\hline jeral & 128 & 1293 & 9.9 & 22 & 485 & 4.5 & & & 8.8 & 41 & 63 & 65.1 & 411 & & . \\
\hline
\end{tabular}

Infs = infections; ptns = patients; $\mathrm{NI}=$ nosocomial infection

There were 128 episodes of nosocomial infections in ward A2, 22 in Ward A3, 220 in ward $R-17$, and 41 in NICU, showing rates of $9.9 \%$ in ward $A 2,4.5 \%$ in ward $A 3$, $8.8 \%$ in R-17, and $65.1 \%$ in NICU. The overall nosocomial infection rate was 9.5\% (Table 1). Table 2 demonstrates the duration of hospital stay of patients with or without nosocomial infections and the overall hospitalized patients during the study. The mean hospital stay of patients with nosocomial infections was 26.77 and 22.44 days in $A 2$ and NICU, while in $A 3$ and $R=17$ was, 17.61 and 6.75 days, respectively. The mean hospital stay of patients and 9.24 days in $\mathrm{A} 2$ and NICU, and 10.48 and 3.10 days in $A 3$ and $R-17$, respectively. The overall mean hospital stay of patients with nosocomial infection was without nosocomial infections was 13.11
Table 2. Duration of hospital stay according to ward

\begin{tabular}{|c|c|c|c|c|c|c|}
\hline \multirow{3}{*}{ Ward } & \multicolumn{6}{|c|}{ Hospital stay (days) } \\
\hline & \multicolumn{2}{|c|}{ All patients } & \multicolumn{2}{|c|}{ With Nls } & \multicolumn{2}{|c|}{ Without NIs } \\
\hline & Mean & S.D. & Mean & S.D. & Mean & S.D. \\
\hline $\mathrm{A} 2$ & 13.93 & 14.7 & 26.77 & 24.41 & 13.11 & 13.15 \\
\hline A3 & 10.67 & 11.8 & 17.61 & 8.19 & 10.48 & 11.85 \\
\hline R-17 & 3.23 & 3.0 & 6.75 & 3.75 & 3.10 & 2.94 \\
\hline NICU & 14.54 & 15.4 & 22.44 & 18.31 & 9.24 & 10.05 \\
\hline Overall & 7.42 & 10.66 & 16.83 & 18.92 & 6.94 & 9.70 \\
\hline
\end{tabular}

$\mathrm{I}=$ intermediate; $\mathrm{R}=$ resistant; $\mathrm{S}=$ sensitive

Table 3. Correlation between duration of hospital stay and site of infections of patients with and without nosocomial infections

\begin{tabular}{lcccc}
\hline & \multicolumn{4}{c}{ Hospital stayu (days) } \\
\cline { 2 - 5 } $\begin{array}{l}\text { Site of infec- } \\
\text { tions }\end{array}$ & \multicolumn{3}{c}{ With Nls } & \multicolumn{2}{c}{ Without NIs } \\
\cline { 2 - 5 } & Mean & S.D. & Mean & S.D. \\
\hline Gastroenteritis & 13.53 & 17.54 & 7.84 & 6.78 \\
Skin infections & 19.277 & 17.87 & 10.07 & 5.79 \\
Bacteremia & 14.96 & 19.53 & 10.17 & 13.17 \\
$\begin{array}{l}\text { Urinary tract } \\
\text { infections }\end{array}$ & 20.05 & 18.56 & 11.66 & 11.37 \\
$\begin{array}{l}\text { Pneumonia } \\
\begin{array}{l}\text { Postoperative } \\
\text { wounds infec- }\end{array}\end{array}$ & 22.00 & 6.60 & 9.03 & 7.01 \\
tions & 32.00 & 37.38 & 5.33 & 4.51 \\
\hline
\end{tabular}

$\mathrm{I}=$ intermediate $\mathrm{R}=$ resistant; $\mathrm{S}=$ sensitive 
Table 4. Hospital stay in ward R-17 according to site of nosocomial infections

\begin{tabular}{lcc}
\hline & \multicolumn{2}{l}{} \\
\hline Site of infections & \multicolumn{2}{c}{ Hospital stay (days) } \\
\hline Gastroenteritis & Mean & S.D. \\
Skin infections & 5.02 & 3.92 \\
Bacteremia & 5.13 & 3.06 \\
Urinary tract infec- & 7.72 & 5.14 \\
tions & 6.40 & 3.40 \\
\hline Overall & & \\
\hline
\end{tabular}

Table 5. Length of stay-spe cific nosocomial infection rates

\begin{tabular}{|c|c|c|c|c|c|c|c|c|c|c|c|c|c|}
\hline \multirow{3}{*}{$\begin{array}{l}\text { Length } \\
\text { of stay } \\
\text { (days) }\end{array}$} & \multirow{3}{*}{$\begin{array}{l}\text { No. of } \\
\text { hospi- } \\
\text { talized } \\
\text { patients }\end{array}$} & \multicolumn{12}{|c|}{ Length of stay - specific nosocomial infection rates } \\
\hline & & $\begin{array}{l}\text { No. } \\
\text { of } \\
\text { Nis }\end{array}$ & $\begin{array}{l}\text { Gastro } \\
\text { en- } \\
\text { teri- } \\
\text { tis }\end{array}$ & $\begin{array}{l}\text { roNo. } \\
\text { of } \\
\text { Nis }\end{array}$ & $\begin{array}{l}\text { Skin } \\
\text { inf. }\end{array}$ & $\begin{array}{l}\text { No. } \\
\text { of } \\
\text { NIs }\end{array}$ & $\begin{array}{l}\text { Bac- } \\
\text { tere- } \\
\text { mia }\end{array}$ & $\begin{array}{l}\text { No. } \\
\text { of } \\
\text { Nis }\end{array}$ & UTI & $\begin{array}{l}\text { No. } \\
\text { of } \\
\text { Nls }\end{array}$ & $\begin{array}{l}\text { Other } \\
\mathrm{N} / \mathrm{s}\end{array}$ & $\begin{array}{l}\text { Total } \\
\text { No. } \\
\text { of }\end{array}$ & Total \\
\hline & & & $\%$ & & $\%$ & & $\%$ & & $\%$ & & $\%$ & & $\%$ \\
\hline Up to 6 & 2783 & 55 & 2.0 & 11 & 0.4 & 19 & 0.7 & 4 & 0.1 & - & - & 89 & 3.2 \\
\hline 13 & 936 & 76 & 8.1 & 34 & 3.6 & 24 & 2.6 & 19 & 2.0 & 3 & 0.3 & 156 & 16.7 \\
\hline $20-$ & 319 & 26 & 8.2 & 17 & 5.3 & 8 & $2.5^{\circ}$ & 9 & .2 .8 & 3 & 0.9 & 63 & 19.7 \\
\hline $27-$ & 103 & 9 & 8.7 & 7 & 6.8 & 4 & 3.9 & 3 & 2.9 & 2 & 1.9 & 25 & 24.3 \\
\hline 34 & 65 & 4 & 6.2 & 6 & 9.2 & 4 & 6.2 & 3 & 4.6 & 2 & 3.1 & 19 & 29.2 \\
\hline $\begin{array}{l}\text { More } \\
\text { than } 35\end{array}$ & 122 & 12 & 9.8 & 18 & 14.8 & 8 & 6.6 & 20 & 16.4 & 1 & 0.8 & 59 & 48.4 \\
\hline
\end{tabular}

tively. The overall mean hospital stay of patients with nosocomial infection was that of without nosocomial infection and overall hospitalized patients, respectively).

Table 3 shows the correlation between duration of hospital stay and site of infections of patients with and without nosocomial infections during the 9-month study. Nosocomial postoperative wound infections had the longest hospital stay, i.e. 32.00 days, followed by nosocomial pneumonia and urinary tract infections, 22.00 and 20.05 days, respectively. The shortest hospital stay was for nosocomial gastroenteritis showing a mean of 13.53 days. For patients without nosocomial infections, urinary tract, bacteremia and skin infections had the longest hospital stay, i.e. $11.66,10.17$ and 10.07 days respectively, whereas postoperative wound infections had the shortest stay, i.e. 5.33 days, followed by gastroenteritis 16.83 days (2.4 and 2.3 times higher than

and pneumonia, 7.84 and 9.03 days respectively.

In the neonatal ward (R-17) the hospital stay according to site of nosocomial infections is shown in Table 4. Nosocomial skin infections had the shortest mean hospital stay, namely only 5.13 days. The longest was for nosocomial bacteremia i.e. 7.72 days.

Table 5 demonstrates clearly that the longer the length of stay, the higher the number of nosocomial infections $(x 2=482.68, d f=5, p)$. The table also shows the length of stay specific nosocomial infection rates according to site of infections. Length of stay-specific nosocomial infection rate was $3.2 \%$ in patients with length of stay up till 6 days. Length of stay-specific nosocomial infection rates were $16.7 \%, 19.7 \%, 24.3 \%, 29.2 \%$ and $48.4 \%$ in patients with length of stay up to 13 days, 20 days, 27 days, 34 days and 35 days or more, respectively.

\section{Discussion}

Nosocomial infection rates in ward $\mathrm{A} 2$, $\mathrm{A} 3, \mathrm{R}-17$ and $\mathrm{NICU}$ were $9.9 \%, 4.5 \%, 8.8 \%$ and $65.1 \%$, respectively. The differences in nosocomial infection rates in the four wards also reflected the diversity of the patient's diseases, the severity of their illness, and socioeconomic status. It could be expected and predicted that the lower the socioeconomic status, the higher the incidence of nosocomial infection. In this study the mean duration of hospitalization was approximately 7.4 days in all patients, and 17 days in patients with nosocomial infections. The mean hospital stay was only 5.7 days for patients who died and the mean hospital stay of all survived patients was 7.5 days. So the shorter hospital stay because of early death did not influence significantly the general mean hospital stay. Janas et al. in Karantina Hospital Jakarta found mean duration of hospitalization of approximately 9 days and 5 days in patients with and without nosocomial infections respectively. ${ }^{7}$ 
Patients with nosocomial skin infection in ward R-17 had the shortest mean hos pital stay, namely only 5 days. The longest stay of 8 days was in patients with nosocomial bacteremia. Thus, though this ward showed the highest frequency (57.5\%) of nosocomial infections, it re vealed the shortest hospital stay for nosocomial infections with a relative mean of approximately 7 days. However, this can not be considered as a positive fact, be cause in this neonatal ward, if the mothe knew that her baby had gastrocnteritis and she herself was discharged after delivery, she forced to bring her child along with her. This was also the reason why the outcome of nosocomial infection is unknown.

The mean hospital stay of all hospital ized patients in ward R-17 was 3.2 days The mean stay was only 2.9 days for patients who died and mean hospital stay of all survived patients in ward R-17 was 3.2 days. So the shorter hospital stay because

\section{Conclusions}

The overall mean hospital stay of patients with nosocomial infection was 2.4 times higher than of without. Not taking into account postoperative nosocomial wound infections and respiratory tract infections as the number was to small, nosocomial

\section{Acknowledgments}

This study has been carried out through the sponsorship of the Belgian Ministry of Development Cooperation (ABOS) and urinary tract infections had the longest hospital stay, while the shortest hospital stay was for nosocomial gastroenteritis.

The longer the length of stay, the higher the number of nosocomial infections.

of early death also apparently did not influence the mean hospital stay of all spitalized patients in ward R-17.

thespitalwith nosocomial infections

stay was 10.00 days for paions. So early death apparently did not influence on hospital stay of patients with (length of stay-spein patients hospitalized up to 6 days, to $48.4 \%$ in patients hospitalized 35 days or So longer the length of stay, the number of nosocomial infectime in the hospital is directly related to the constant risk of nosocomial infections.

Ford Foundation (Project No. 870-1714). It is appropriate to acknowledge the invaluable contribution of the Nosocomial
Infection Working Group members of School of Medicine, Padjadjaran University, Hasan Sadikin General Hospital Bandung, and Prof. S. Lauwers from the

Department of Microbiology Academisch Ziekenhuis-Vrije Universiteit Brussel (VUB), Belgium.

\section{References}

Wakefield DS, Helms CM, Massanari RM, Mori $M$. Pfaller MA.Cost of nosocomial infection $M$. Pfaller MA.Cost of nosocomial infection Relative contributions of laboratory, antibiotic, aureus infections. Am J Infect Contr 1988;16: aureus inied
$185-92$.

2. Haley RW, Schaberg DR, Von Allmen SD, McGowan JE. Estimating the extra charges and prolongation of hospitalization due to nosocomial infections : a comparisor

3. Green MS, Rubinstein E, Amit P. Estimating the effects of nosocomial infections on the length of hospitalization. J Infect Dis 1982. 145. 667.72.

4. Wenzel RP. Nosocomial infections, diagnosisrelated groups and study on the efficacy of nosocomial infection control-economic implica- tions for hospitals under the prospective payment system. Am J Med 1985; 78:3-7.

5. Haley RW, Culver DH, White JW, et al. The efficacy of infection surveillance and control programs in preventing nosocomial infections
in US hospitals. Am J Epidemiol 1985; 121:182205.

6. Girard R, Fabry J, Maynet R, Lambert DC, Sepetjan $M$. Costs of nosocomial infection in a neonatal unit. J Hosp Infect 1983; 4:361-6.

7 Janas, Sutoto, Punjabi NH. Infeksi nosokomial saluran cerna (INSC) pada penderita anak di Rumah Sakit Karantina Jakarta. Kumpulan Palembang, 1984; 385-98. 